\title{
Corporate Social Responsibility from Friedman to Porter and Kramer
}

\author{
Maria Teresa Bosch-Badia, Joan Montllor-Serrats, Maria Antonia Tarrazon \\ Department of Business Economics, Autonomous University of Barcelona, Barcelona, Spain \\ Email: Joan.Montllor@uab.cat
}

Received April 10, 2013; revised May 9, 2013; accepted June 9, 2013

Copyright (C) 2013 Maria Teresa Bosch-Badia et al. This is an open access article distributed under the Creative Commons Attribution License, which permits unrestricted use, distribution, and reproduction in any medium, provided the original work is properly cited.

\begin{abstract}
We analyze, from the viewpoint of value creation, the evolution of Corporate Social Responsibility (CSR) thought from Friedman critical view of CSR to Porter and Kramer "shared-value" proposition, emphasizing, at the same time, its parallelism with the evolution of asset valuation models from the viewpoint of common stocks value. On this basis, we show how CSR has adapted to value creation, the corporate goal that has substituted the old goal of profit maximization. A review of the studies about the impact of CSR on corporate financial performance complements this analysis.
\end{abstract}

Keywords: Corporate Social Responsibility; Corporate Financial Performance; Real Options; Stakeholders

\section{Introduction ${ }^{1}$}

Corporate Social Responsibility (CSR) is a key issue for modern corporations and, of course, for modern society. Since it began to be regarded as a relevant topic to nowadays, its practice and the theory behind it have substantially changed. The aim of this article is to analyze the evolution of economic and strategic thought on CSR from Friedman's [1] critical view to Porter and Kramer [2] shared value proposition. We draw the conclusion that value creation has evolved in parallel to CSR: the former does not longer exclusively consists of profit maximization, and the latter has turned from an expense into an investment. CSR consists of the courses of action that firms undertake to become environmentally and socially sustainable beyond their legal obligations. From the financial viewpoint, in the short run, CSR means a decrease in profits for the sake of a social or environmental end. Its roots lie in demands from society and law makers for correcting market failures as the essential driver of both individual and corporate social responsebilities (Bénabou and Tirole [3]). Thus, we can say that CSR has added a third dimension to the two primitive coordinates of demand, i.e. to price and quality. The paper is organized as follows: Section 2 analyses the evolution of CSR thought from Milton Friedman to stakeholder's theory. In Section 3, we study the links between

${ }^{1}$ We thank an anonymous referee for helpful comments.
CSR and value creation. First we center on the works that identify CSR as a value driver and, next, we focus on Porter and Kramer shared value proposition. Section 4 is devoted to the parallel evolution of asset valuation models and CSR thought. Section 5 complements the previous analysis by revising the evolution of CSR from the perspective of the empirical works. Section 6 closes the article.

\section{Friedman vs. Stakeholder's Theory}

At nineteen sixties, when interest for CSR began, it was regarded as an expense on philanthropy which aim was returning profits to society. Thus, from the financial viewpoint it meant a decrease in profits for the sake of a social or environmental end. On this basis, Milton Friedman [1] wrote the famous article entitled The Social Responsibility of Business is to Increase its Profits, where he held that those executives who imposed social expenses to the corporations they managed should be regarded as disloyal agents to their principals, the shareholders. In fact, if profits are the only value driver, it becomes clear that any reduction in earnings without any complementary effect, whether it comes from philanthropy, destroys value. Nevertheless, since value comes from discounting expected profits at the required rate of return, with risk premium inside, we have to consider the impact of CSR on risk, and, therefore, on the discounting 
rate. Several works, (Orlitzky and Benjamin [4]; Husted [5]; Kitzmueller and Shimshack [6]) point out that CSR hedges social risk, i.e. the risk that comes from social activism or private politics. The logical next step is to acknowledge that it creates value through risk reduction. Kitzmueller and Shimshack [6] also underline that CSR is an instrument to reduce public political risk. To this extent, CSR, even if it exclusively consists of philanthropic expenses, it creates value through risk reduction.

The main argument against Friedman's criticism has come from stakeholders' theory introduced by Freeman [7]. Corporate governance does not only take into account shareholders' interests, but also the interests of other stakeholders, like employees, customers, suppliers and communities directly affected by corporate actions. The Halal Return-on-Resources Model [8] clarifies the resources invested by each stakeholders group and their benefits, costs and return. Halal [8] points out the centrality of integrating the various social interests into corporate goals and shows the myopia that pervades the philosophy that considers profits alone as the unique legitimate goal of business. Haigh and Jones [9] identify as the CSR drivers the pressures that come from different stakeholders: the corporation itself, competence, investors, consumers, regulators and popular mobilizations. A CSR policy that takes into account stakeholder requirements may add competitive advantage in some corporate areas. For instance, non-monetary conditions of employment can be regarded as a positive signal to attract quality work force (Kitzmueller and Shimshack [6]) while environmental care and better relationships with government and communities may smooth the requirements for opening new plants. CSR also facilitates to attract investments from ethical mutual funds.

\section{Corporate Social Responsibility and Value Creation}

\subsection{Identifying CSR as a Value Driver}

The conceptual enlargement brought by stakeholder's theory has lead to identify CSR as a value driver. Burker and Logsdon [10] find five dimensions of corporate strategy that enable to relate CSR to value creation: Centrality (closeness to the firm's mission and objectives), specificity (ability to capture private benefits by the firm), proactivity (planning in anticipation of social trends), voluntarism, and visibility (projects observable by stakeholders). Epstein, Buhovac, and Yuthas [11] approach CSR from the paradox theory perspective showing that the tensions between CSR and Corporate Financial Performance (CFP) are a source of creative ideas for managers. Vilanova, Lozano, and Arenas [12] argue that CSR and competitiveness relate through learning and innovation cycle. Fernández and Luna [13] examine how corporate reputation contributes to create value. Freeman, Harrison, Wicks, Parmar, and Colle [7] make a distinction between the residual concept of CSR, focused on returning profits to society, and integrated CSR. The integrated approach regards CSR as a part of the corporate competitive strategy: it conceptualizes CSR as the integration of social, ethical and environmental concerns into the management criteria for corporate strategy. The role of managers consists of interweaving stakeholders demands with corporate capacities in order to create value by respecting the rules that regulate corporate behaviour. Nevertheless, the relationship between CSR and value creation is mainly due to the articles by Michael Porter and his co-authors Kramer and Van der Linde. Porter and Van der Linde [14] regard expenses in reduceing environmental impact as an opportunity to improve competitiveness. Porter and Kramer [15], writing on corporate philanthropy, also advocate for strategic giving, i.e. for charitable efforts that contribute to society and improve the corporate competitive context, instead of giving pure donations that, at most, enable cause-related marketing. The same authors [16] hold that CSR, analyzed using the same framework that guides corporate business choice becomes a source of opportunity, innovation, and competitive advantage. The basis of this statement is the distinction between responsive CSR and strategic CSR. The former is addressed to returning profits to society. The latter is addressed to identifying societal problems that the corporation can contribute to solve, and, as a consequence, create value simultaneously for society and shareholders.

\subsection{The Porter and Kramer Proposition: Shared Value}

The last step of the evolution of Porter and Kramer [2] thought on the relationships between corporations and society is the concept of shared value. The corporationcentered value creation perspective gives way to a corporation-stakeholders perspective. The basis of this new approach is to recognize that societal needs, not just conventional economic needs, define markets. Ultimately corporations, by assuming shared-value strategies, have the opportunity to turn capitalism into an environmentally, socially and financially sustainable economic system. In the long run, shared value leads to a stronger and more sustainable value chain, but, in the short run it faces the capital markets pressure for short term profits. At this point, it is worth remembering that common stock prices reflect available information (Fama [17], although they can be distorted by noise (Black [18]), anomalies, and bubbles (Malkiel [19]). Long term sustainability can be assimilated to information and pressures for short term profits to noise. For this reason, a central goal of corporate 
communication policy is to make investors aware of the fact that long term sustainability deserves a greater weight than short term profits in any sensible stock value estimation.

To sum up, the evolution of the theoretical thought on CSR can be synthesized in three stages: philanthropy, evolution from philanthropy to value creation, and shared value. The latter can be regarded as the whole integration of CSR into corporate strategy. The problem with regarding and managing CSR as a policy exclusively aimed at returning profits to society is that, in the end, shares value would become a decreasing function of CSR, and; thus, CSR would not be financially sustainable. The managerial challenge with respect to CSR is to turn it from an expense into an investment (Husted and Allen [20]), to create value through it and to make shareholders aware of this value creation.

\section{The Parallel Evolution of Asset Valuation Models}

\subsection{Discounting Cash Flow Models: Dividend Growth vs. the Present Value of Growth Opportunities}

Asset valuation models have experienced an evolution that parallels the evolution of CSR thought. At the moment at which Friedman wrote his article on CSR, the discounting cash flow technique was, by large, the dominant model. The two main models in this field are the dividend growth model and the present value of growth opportunities. The dividend growth model $^{2}$ (Williams [22], Gordon and Shapiro [23]) considers dividends, their growth and the required rate of return as the variables that determine common stock prices. Therefore, it exactly fits with the profit maximization paradigm and Friedman's viewpoint.

Miller and Modigliani [24], in their article on dividend policy and shares valuation, develop a model in which the value of common stock is obtained as the addition of the discounted earnings generated by current assets and the future opportunities of undertaking new projects with positive net present value. The theoretical approach by Miller and Modigliani has lead to applied models that follow this line, such as the ones developed by Brealey and Myers [25] in the first edition of their textbook, Leibowitz and Kogelman [26] and O’Brien [27]. These models widen the valuation scope by making explicit the relevance of new opportunities. Since their perspective, value maximization is not only the outcome of the maximization of the profits generated by current operations. It also depends on the outcome of one of the central func-

\footnotetext{
${ }^{2}$ As Brealey, Myers and Allen [21] point out, the dividend growth model was first deduced by Williams [22], and later rediscovered by Gordon and Shapiro [23].
}

tions of managerial strategic thinking: capturing and creating new opportunities. Thus, they provide the basis to connect CSR to value creation.

\subsection{Flexibility and the Value of New Opportunities: Real Options}

In the second half of the nineties option valuation began to be applied beyond the option contracts traded in derivatives markets. Real options were introduced in financial literature (Trigeorgis [28]) and on strategic thinking (Luehrman [29]; Amran and Kulatilaka [30]). The new valuation approach emphasized that value not only comes from undertaking projects that maximize the present value of profits, but also from projects that bring the opportunity to start new projects in the future. Although only few articles directly relate CSR with real options (Husted [5]), the link between the new value creation opportunities embedded in CSR strategies and real options is fairly clear. In other words, if from the discounted cash flow viewpoint the value creation capacity of CSR often remains fuzzy, real options enlighten the relationship between CSR and value creation.

\section{The Empirical Analysis on CSR}

Empirical analysis on CSR has been mainly concerned with its relationship with corporate financial performance (CFP). Three conclusions can be drawn from revising the literature on the empirical evidence on the effects of CSR on CFP. First, the relationship between CSR and CFP has evolved from a nil or low correlation to a positive correlation. Second, CSR positively impacts on CFP in the long run. Third, CSR creates value mainly when it is focused on primary stakeholders, but it has an insurance effect when it has a wider orienta1tion. McWilliams and Siegel [31] find that the impact of CSR on CFP is neutral after separating it from the influence of $R \& D$. The meta-analysis performed by Orlitzky, Schmidt and Rynes [32], and Margolis and Walsh [33], conclude that CSR predominantly shows a low positive impact on CFP. The latter is reviewed by Margolis and Elfenbein [34], where the authors conclude that investments need to be judged solely on the merits, and leaders can and should explore their own motivations before buying into the hype. The more recent literature review by Beurden and Gössling [35], finds that there exists a positive correlation between CSR and CFP in the studies they consider, and draw the conclusion that there is a change in this correlation with respect to its observed value in previous works. Roberts and Dowling [36] argue that CSR positively contributes to the long term sustainability of CFP. Shank, Manullang and Hill [37] find that, in the long run, CSR and CFP have a significant correlation, but not in the short run. According to Hillman and Keim [38], there is a significant 
positive correlation between CSR and CFP when the former is focused on primary stakeholders, but a nil correlation in other circumstances. On the other hand, Godfrey, Merrill and Hansen [39], find that CSR focused on secondary stakeholders has an insurance effect that creates value for shareholders in case of negative events. The synthesis of these three conclusions leads to realize the relevance of real options to link CSR with CFP. The temporal lag between the growth of CSR and its association to value creation can be attributed to the fact that financial markets may not have become aware of the financial value of CSR expenses until they have begun to regard them as a source of opportunities to undertake new investments, i.e. as real options. The long run impact of CSR on corporate value fits with the interaction of creating real options and, after some years, exercising the ones that have become really valuable. This is a value chain that attracts investors who look for the long run profitability, instead of trying to make profits from short run volatility. Finally, real options arise mainly from the relationships between the corporation and its primary stakeholders. The insurance effect pointed out by Godfrey, Merrill and Hansen also has option features that we consider below. Shared value, in turn, opens a new field for value creation.

\section{Conclusion}

From this overview of the evolution of CSR thought, we can draw the conclusion that it has evolved from returning profits to society to creating shared value with stakeholders in order to improve the environmental and social corporate sustainability. The collateral activity that CSR was at the beginning has become part of the core corporate strategy. Financially, philanthropic expenses have turned into investments with shared value creation ends. Friedman criticized CSR for its capacity to spoil corporate value assuming that it was limited to philanthropic expenses that enhanced the managerial ego. Nevertheless, capitalism has found the way of integrating CSR into value creation. In effect, even if CSR does not maximize earnings directly, it contributes to the end that profit maximization had assigned in old valuation methods: value creation.

\section{REFERENCES}

[1] M. Friedman, "The Social Responsibility of Business Is to Increase Its Profits,” The New York Times Magazine, 13 September 1970.

[2] M. E. Porter and M. R. Kramer, "Creating Shared Value,” Harvard Business Review, Vol. 89, No. 1, 2011, pp. 2-17.

[3] R. Bénabou and J. Tirole, "Individual and Corporate Social Responsibility,” Economica, Vol. 77, No. 305, 2010, pp. 1-19. doi:10.1111/j.1468-0335.2009.00843.x
[4] M. Orlitzky and J. D. Benjamin, "Corporate Social Performance and Firm Risk, a Meta-Analytic Review,” Business and Society, Vol. 40, No. 4, 2001, pp. 369-396. doi:10.1177/000765030104000402

[5] B. V. Husted, "Risk management, Real Options, and Corporate Social Responsibility,” Journal of Business Ethics, Vol. 60, No. 2, 2005, pp. 175-183. doi:10.1007/s10551-005-3777-1

[6] H. Kitzmueller and J. Shimshack, "Economic Perspectives on Corporate Social Responsibility," Journal of Economic Literature. Vol. 50, No. 1, 2012, pp. 51-84. doi:10.1257/jel.50.1.51

[7] R. E. Freeman, J. S. Harrison, A. C. Wicks, B. L. Parmar and S. de Colle, "Stakeholder Theory," Cambridge University Press, Cambridge, 2010. doi:10.1017/CBO9780511815768

[8] W. E. Halal, "Business and Government-A New Partnership?” Long Range Planning, Vol. 20, No. 1, 1987, pp. 123-130. doi:10.1016/0024-6301(87)90040-9

[9] M. Haigh and M. T. Jones, "The Drivers of Corporate Social Responsibility, a Critical Review,” The Business Review, Vol. 5, No. 2, 2006, pp. 245-251.

[10] L. Burke and J. M. Logsdon, "How Corporate Social Responsibility Pays off,” Long Range Planning, Vol. 29, No. 4, pp. 495-502. doi:10.1016/0024-6301(96)00041-6

[11] M. J. Epstein, A. R. Buhovac and K. Yuthas, "Managing Social, Environmental and Financial Performance Simultaneously,” Long Range Planning, Unpublished.

[12] M. Vilanova, J. Lozano and D. Arenas, "Exploring the Nature of the Relationship between CSR and Competitiveness," Journal of Business Ethics, Vol. 87, No. 1, 2009, pp. 57-69. doi:10.1007/s10551-008-9812-2

[13] J. L. F. Sánchez and L. L. Sotorrío, "The Creation of Value through Corporate Reputation,” Journal of Business Ethics. Vol. 76, No. 3, 2007. pp. 335-346.

[14] M. E. Porter, M. E. and C. Van der Linde, "Green and Competitive, Ending the Stalemate," Harvard Business Review, Vol. 73, No. 5, 1995, pp. 120-121.

[15] M. E. Porter and M. R. Kramer, "The Competitive Advantage of Corporate Philanthropy," Harvard Business Review, Vol. 80, No. 9, 2002, pp. 56-69.

[16] M. E. Porter and M. R. Kramer, "Strategy \& Society, the Link between Competitive Advantage and Corporate Social Responsibility,” Harvard Business Review, Vol. 84, No. 12, 2006, pp. 78-92.

[17] E. Fama, "Efficient Capital Markets: A Review or Theory and Empirical Work,” Journal of Finance, Vol. 25, No. 2, 1970, pp. 383-417. doi:10.2307/2325486

[18] F. Black, “Noise,” Journal of Finance, Vol. 41, No. 3, 1986, pp. 529-543.

[19] B. Malkiel, “A Random Walk down Wall Street,” W. W. Norton \& Company, New York, 2011.

[20] B. W. Husted and D. B. Allen, "Strategic Corporate Social Responsibility and Value Creation among Large Firms, Lessons from the Spanish Experience,” Long Range Planning, Vol. 40, No. 6, 2007, pp. 594-610. doi:10.1016/j.lrp.2007.07.001 
[21] R. Brealey, S. C. Myers and F. Allen, “Corporate Finance,” 8th Edition, McGraw Hill, New York, 2006.

[22] J. B. Williams, “The Theory of Investment Value,” Harvard University Press, Cambridge, 1938.

[23] M. J. Gordon and E. Shapiro, "Capital Equipment Analysis: The Required Rate of Profit,” Management Science, Vol. 3, No. 1, 1956, pp. 102-110. doi:10.1287/mnsc.3.1.102

[24] M. Milller and F. Modigliani, "Dividend Policy, Growth and the Valuation of Shares," The Journal of Business, Vol. 34, No. 4, 1961, pp. 411-433. doi:10.1086/294442

[25] R. Brealey and S. C. Myers, "Principles of Corporate Finance,” McGraw Hill, New York, 1981.

[26] M. L. Leibowitz and S. Kogelman, "Inside the P/E Ratio: The Franchise Factor,” Financial Analysts Journal, Vol. 46, No. 6, 1990, pp. 17-35. doi:10.2469/faj.v46.n6.17

[27] T. O’Brien, “A Simple and Flexible DCF Valuation Formula,” Journal of Applied Finance, Vol. 13, No. 2, 2003, pp. 54-62.

[28] L. Trigeorgis, "Real Options and Interactions with Financial Flexibility,” Financial Management, Vol. 22, No. 3, 1993, pp. 202-224. doi:10.2307/3665939

[29] T. A. Luehrman, "Strategy as a Portfolio of Real Options," Harvard Business Review, Vol. 76, No. 5, 1998, pp. 8999.

[30] M. Amram and N. Kulatilaka, "Disciplined Decisions, Aligning Strategy with the Financial Markets,” Harvard Business Review, Vol. 77, No. 1, 1999, pp. 95-104.

[31] A. McWilliams and D. Siegel, "Corporate Social Responsibility and Financial Performance, Correlation or Misspecification?” Strategic Management Journal, Vol. 21, No. 5, 2000, pp. 603-609. doi:10.1002/(SICI)1097-0266(200005)21:5<603::AID-S $\underline{\mathrm{MJ} 101>3.0 . \mathrm{CO} ; 2-3}$
[32] M. Orlitzky, L. Schmidt and S. L. Rynes, "Corporate Social and Financial Performance, a Meta-Analysis," Organization Studies, Vol. 24, No. 3, 2003, pp. 403-441. doi:10.1177/0170840603024003910

[33] J. D. Margolis and J. P. Walsh, "Misery Loves Companies, Rethinking Social Initiatives by Business," Administrative Science Quarterly, Vol. 48, No. 2, 2003, pp. 268-305. doi:10.2307/3556659

[34] J. D. Margolis and H. A. Elfenbein, "Do Well by Doing Good? Don't Count on It," Harvard Business Review, Vol. 86, No. 1, 2008, pp. 19-20.

[35] P. Beurden and T. Gössling, "The Worth of Values-A Literature Review on the Relation between Corporate Social and Financial Performance,” Journal of Business Ethics, Vol. 82, No. 2, 2008, pp. 407-424. doi:10.1007/s10551-008-9894-X

[36] P. W. Roberts and G. R. Dowling, "Corporate Reputation and Sustained Superior Financial Performance,” Strategic Management Journal, Vol. 23, No. 1, 2002, pp. 10771093.

[37] T. Shank, D. Manullang and R. Hill, "Doing Well While Doing Good Revisited, a Study of Socially Responsible Firms' Short-Term versus Long-Term Performance," Managerial Finance, Vol. 31, No. 8, 2005, pp. 33-46.

[38] A. J. Hillman and G. D. Keim, "Shareholder Value, Stakeholder Management, and Social Issues, What's the Bottom Line?” Strategic Management Journal, Vol. 22, No. 2, 2001, pp. 125-139. doi:10.1002/1097-0266(200101)22:2<125::AID-SMJ150 $>3.0 . \mathrm{CO} ; 2-\mathrm{H}$

[39] P. C. Godfrey, C. B. Merrill and J. M. Hansen, “The Relationship between Corporate Social Responsibility and Shareholder Value, an Empirical Text of the Risk Management Hypothesis," Strategic Management Journal, Vol. 30, No. 4, 2009, pp. 425-445. doi:10.1002/smj.750 